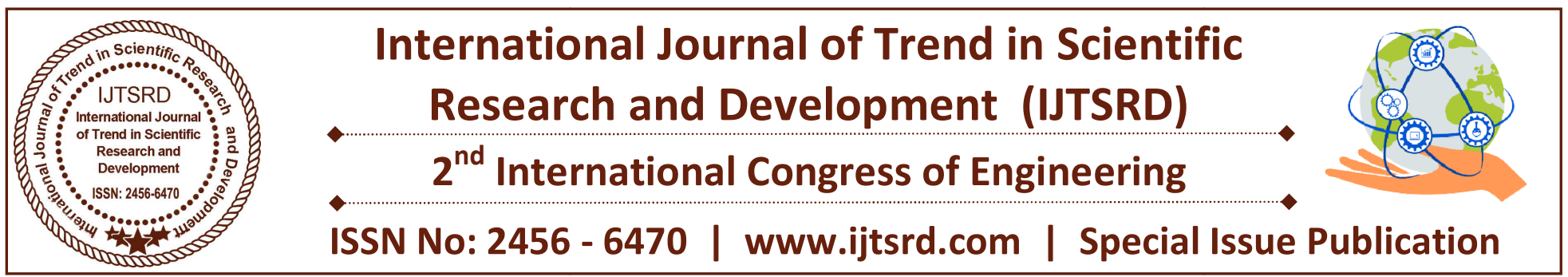

\title{
Improvement in the process of production planning applying the simplex method
}

\author{
${ }^{1}$ González Torres Arturo, ${ }^{1}$ García Araiza Oscar S., ${ }^{1}$ Ramírez Castañeda Armando I., \\ ${ }^{2}$ García Parada Ricardo y, ${ }^{2}$ García González Juan M. \\ ${ }^{1}$ Tecnológico Nacional de México \\ Instituto Tecnológico de Tláhuac II \\ ${ }^{2}$ Tecnológico Nacional de México \\ Instituto Tecnológico de Chihuahua II
}

\begin{abstract}
The manufacture of metal-mechanical parts is very important in the industrial field. Due to the increasing demand in the market, the company under study decided to develop the application of this method, to be able to know the production planning of its products. This study is limited to two products with the most demand currently: product $\mathrm{A}$ and product. A time study with a $95 \%$ confidence interval was also performed to determine the average processing time for each product, as well as the limits of each product. The result of the present investigation was to know the planning of the production of the two products with the most demand.
\end{abstract}

Keywords: Simplex method, industrial company, improvement

\section{INTRODUCTION}

The term Operations Research (IO) is first used in 1939 during World War II, specifically when the need arises to investigate the tactical and strategic operations of air defense, with the incorporation of a new radar, in opportunity of the German attacks on Britain. The accelerated advance of military technology has led British military executives and administrators to turn to scientists for support and guidance in planning their defense. The success of a small group of scientists who worked together with the military executive in charge of operations on the "line" led to a greater demand for their services and the extension of the use of the methodology to USA,
Canada and France between others (Universidad de la República Oriental del Uruguay, 2016).

Alvarado (2009) points out that in the beginning the linear programming was known as Programming in a Linear Structure. According to Anderson Sweeney and Williams (2004), in 1948 Tjalling Koopmans told Dantzig that the name was too long and that it was convenient to change it, before which Dantzig agreed and the name was replaced by Linear Programming, which is even used nowadays. Taha (2004) in his book points out that a major element of operations research is mathematical modeling. Galicia (2013) notes that operations research is a branch of mathematics, focused on the study of mathematical models, statistics and algorithms, with the aim of helping the decision-making process. The first journal published in the operational field was Operational Research Quarterly, edited by the Operational Research Society in 1950. The following was Operatians Research, published in America by ORSA (Jimenez, 2009).

A definition of this concept is proposed by Durán (2006), this concept is the science of decision making. Similarly, Duran (2006) points out that in this discipline, professionals from the most diverse branches: engineers, mathematicians, computers, economists. All of them must learn a fundamental technique: mathematical modeling. Prawda (2000) points out that operations research is the application of the scientific method to decision-making problems 
that provides methods that can represent and solve by mathematical models a real problem of a system, finding and controlling the relations between the components in order to evaluate the results associated with the stated objectives and to establish the necessary actions to modify the behavior patterns of said components. Izar (1996) defines operations research as a group of methods and techniques applicable to solving operating problems of systems.

Illés and Terlaky (2002) point out that mathematical optimization is one of the main branches of applied mathematics. Since its discovery in the mid-twentieth century, it is considered one of the most controversial fields of mathematical research. Marchena, Ornelas, and González (2007) point out that the purpose of linear programming is to optimize (minimize or maximize) a linear function of $n$ variables subject to linear constraints of equality or inequality, called the objective function.

\section{Awards}

Jiménez (2009) points out that to know the main practical works in Operative Research can consult the Interfaces magazine published bimonthly INFORMS. Continuing with the ideas of Jiménez (2009), the awards given to important works of Operative Research, either for their applied interest or for the development of new theories, have been an important stimulus when planning and directing concrete lines of research. Some of these prizes have had an important historical and have been more fashionable in a few years than others. We can mention, among others, the following prizes:

The Lanchester Prize, awarded annually by ORSA (now that it has been integrated into INFORMS, granted by this institute) for the best publication in Operations Research in English language. It is granted since 1954, and in 1994 it had a monetary endowment of $\$ 5000$.

Dantzig Award, awarded every three years by the Mathematical Programming Society and the Society for Industrial and Applied Mathematics for the best original contribution to the field of Mathematical Programming.

Fulkerson Award, awarded every three years by the American Mathematical Society and the Mathematical Programming Society for the most brilliant research article in the field of Discrete Mathematics.

Orchard-Hays Award, awarded every three years by the Mathematical Programming Society for excellence in Computational Mathematical Programming.

\section{Simplex Method}

Since George B. Dantzig developed the simplex method in 1947, linear programming has been widely used in military, industrial, governmental and urban planning, among others (Bazaraa and Javis, 1996).

The Simplex Method is a basic mathematical tool in decision making, but it requires understanding each of its steps and the constancy of practicing them. Minimizing costs or maximizing profits will depend on the needs of each company or subject, the paths to take them are infinite, but when it comes to more than two variables, the really optimum path is right at this moment in your hands (Valencia, 2015). Morales (2012) points out that the operation of this method is as follows, we are looking for feasible solutions at the extreme points of the solution space until the objective function can not be further improved. The simplex method has been widely used for the unambiguous optimization of different analytical procedures; particularly in cases where there is an interdependence of the variables to be optimized. Compared to other optimization methods based on experimental designs or response surfaces, the simplex method generally allows the optimum to be reached in a simpler and faster way (Rodríguez, Díaz, Amanda, Ahumada and Guerrero, 2013).

Ariza (S / A) points out that the simplex method is a mathematical tool that solves planning and scheduling problems; that is, it solves the question about how much to produce according to the operational capacity and market studies. Also, this method uses the Linear Programming model, through the solution of a matrix, using the method of elimination of Gauss Jordan.

Instituto Internacional de Investigación de Tecnología Educativa S.C. (2009) points out that the standard or canonical form of the linear programming model is composed of an objective function and a set of constraints. In general, the standard form of the linear programming model can be expressed as: 
Subject to:

$$
Z_{\text {Max }}=C_{1} X_{1}+C_{2} X_{2}+\ldots+C_{n} X_{n}
$$

$$
\begin{aligned}
& a_{11} x_{1}+a_{12} x_{2}+\ldots+a_{1 n} x_{n} \leq b_{1} \\
& a_{21} x_{1}+a_{22} x_{2}+\ldots+a_{2 n} x_{n} \leq b_{2} \\
& \cdot \\
& \cdot \\
& a_{m 1} x_{1}+a_{m 2} x_{2}+\ldots+a_{m n} x_{n} \leq b_{m} \\
& x, x_{2} \ldots x_{n} \geq 0
\end{aligned}
$$

And its matrix form is given by the expression:

$$
Z_{\text {Max }}=C X
$$

Subject to:

$$
\begin{aligned}
& A X \leq B \\
& X \geq 0
\end{aligned}
$$

Where:

$\mathrm{C}=\mathrm{It}$ is the matrix of costs or utilities, formed by the coefficients of the objective function.

$A=$ is the matrix of coefficients of the system formed by the constraints.

$\mathrm{B}=$ is the column matrix of independent terms of the constraint system.

$\mathrm{X}=$ is the column matrix of the variables $\mathrm{X} 1, \mathrm{X} 2, \mathrm{X} 3$, $\ldots, \mathrm{Xn}$ of the constraint system.

Romero, Muñoz, and Romero (2006) point out that Industrial Engineering as a discipline dedicated to the design, innovation, improvement, installation and administration of integrated systems of human resources, materials, equipment and technologies, organized for efficient and manufacturing and services. Acevedo and Linares (2012) point out that Industrial Engineering has been boosted since the industrial revolution, its importance grows by its efficient contribution to efficiency and business productivity that leads to new levels, the competitiveness of industrial sectors in the countries.

Guédez (2011) points out that linear programming (PL) is part of mathematical programming and is an optimization technique to deal with problems of allocation of scarce resources between competing activities, dealing exclusively with objective functions and linear constraints.

Schwarz (2014) points out that, within the professional career of industrial engineering, an area of research is the research of operations. The lines of investigation that emerge from there are:

$>$ Optimization of operations and processes

$>$ Route and transport scheduling

$>$ Location of Facilities

$>$ Process simulation

$>$ Solutions with Artificial Intelligence techniques

Kowalski, Enríquez, Santelices, and Mercedes (2015) In engineering careers, and in the case of Industrial Engineering, algorithms occupy an important place, particularly in the discipline Operative Research.

\section{Applications of the simplex method}

This method or procedure has countless applications in linear programming, but also use in mathematics and geometry. Among the most common applications of the simplex method are (Martínez, 2012):

It is a technique used to give numerical solutions to problems of linear programming.

It is commonly applied to find an optimal solution to problems of maximization and minimization.

It is useful for solving large and complex problems.

Variables commonly used in linear programming have been developed from the simplex method.

This method has been extremely useful for the development of software that facilitates the calculation process. An example of this is the WIN QSB ${ }^{\circledR}$

This model is used for the correct interpretation of decision models based on mathematical descriptions in order to help in decision making in situations of uncertainty. 


\section{Importance}

Establishing a production schedule for a period of weeks or months turns out to be a difficult and important task in most production plants. The operations manager must consider many factors: labor, inventory and storage costs, space constraints, demand, etc. Generally, most plants produce more than one good, making the previous task even more complicated (Faulin, S / A). Corominas (2010) notes that operations management gives tools to solve the planning problem raised. In particular, aggregate planning is a typical case of the research area. Aggregate planning is an instrument to forecast, in the medium term, the activities of the area of operations. It is clear that the results of aggregate planning have a large impact on the planning and coordination of resources throughout the organization, there is a tendency to include in the aggregate planning decisions of other functional areas of the company, such as personnel, accounting and finance, procurement or marketing.

Geovanah (2017) points out that the simplex process is a powerful, sophisticated approach to innovation. It is suitable for projects and organizations of almost any scale. This process is an eight-stage cycle. At the end of the eight stages, you have to start again to find and solve another problem, thus helping to ensure continuous improvement.

\section{Success stories}

IOSA Operations Research S.A. (2016) in its page presents different achievements that the companies have had when implementing the simplex method. For example, the following examples stand out:

$>$ CHILEXPRESS. Project: Models of optimization and simulation of Courier routes nationwide in Chile.

Agricultural Society DROKASA S.A Project: Optimized planning of the asparagus harvest master planning model for opening and closing fields.

Minera Yanacocha S.A. Newmont Gold Company - Peruvian Branch. Project: Development of Mathematical Models Oriented to Long-Term Planning.
Union of Peruvian Breweries Backus and Johnston S.A.A. Project: Development of Mathematical Models for the Planning of Supply of Malta to Plants (Decision Support System SSD).

\section{PHP SIMPLEX®}

PHPSimplex ${ }^{\circledR}$ is an online tool for solving linear programming problems. Its use is free and free. To access it simply click on the icon on the left, or on "PHPSimplex" in the top menu (PHPSimplex, 2017). PHPSimplex ${ }^{\circledR}$ is able to solve problems using the Simplex method, the Two Phases method, and the Graphical method, and has no limitations on the number of decision variables or problem constraints (PHPSimplex, 2017).

\section{Winqsb®}

The initial version of the software Winqsb ${ }^{\circledR}$ called at that time QSB, was created in 1985 by Yin-Long Chang professor of the Georgia Institute of Technology (Henríquez and Hernández, 2010). Lugay (2014) points out that Winqsb ${ }^{\circledR}$ software, which is the intellectual property of Dr. Yih-Long Chang, consists of a series of individual modules or applications that help in the investigation of operations, work study, planning and control of the production, project evaluation, quality systems, simulation, statistics, etc., and there are a total of 19 modules, one for each type of problem.

\section{General objective}

Improve the production planning process by applying the simplex method.

\section{Specific objectives}

Understand the contextualization of the topic.

Know the existing models to evaluate the quality of an industrial process.

Calculate the representative sample using $90 \%$ reliability and $10 \%$ error.

Apply the simplex method for the planning of an industrial process. 
$>$ Analyze the results obtained from the analysis of the simplex method for the planning of an industrial process.

Evaluate the results obtained from the analysis of the simplex method for the planning of an industrial process.

\section{Justification}

The understanding of the Simplex Method is important because it allows solving problems of linear programming, which is one of the most important techniques for formulating and solving various decision-oriented problems in the different areas of Engineering. Many companies are unaware that mathematical techniques exist that help to solve their own processes in a practical and easy way. The research is justified by the importance that the application will have in a production process, which will serve to have knowledge of its production planning.

\section{Investigation methodology}

The steps that were followed to develop the project are presented in figure 1 .

\section{Delimitación \\ del problema}

Modelación

del

problema

Resolución

del modelo

Figure 1. Example of project activities

For the Delimitation stage of the problem, a work sample was performed. The industrial process of two products was taken into account. The formula used was the one proposed by Dr. Bolaños (2012), which is used for finite or known populations. The formula is as follows:

$$
n=\left[\frac{Z_{\alpha}^{2} * p^{*} q}{i^{2}}\right]
$$

Where:

n: sample size

$Z$ : value corresponding to the gauss distribution, for research $Z=90 \%$, which is equivalent to 1,645 .

$\mathrm{p}$ : expected prevalence of the parameter to be evaluated, if not known $(\mathrm{p}=0.5)$, which makes the sample size larger.

$\mathrm{q}: 1$ - $\mathrm{p}($ if $\mathrm{p}=70 \%, \mathrm{q}=30 \%)$

$\mathrm{i}$ : error expected to be committed if it is $10 \%, \mathrm{i}=0.10$

The development of the formula is as follows: 


$$
n=\left[\frac{(1.645)^{2} *(0.5) *(0.5)}{(0.10)^{2}}\right]=\frac{67.65}{0.01}=67.65=68
$$

The study indicated that for the investigation of the production process, using $90 \%$ of reliability and $10 \%$ of allowed error, 68 observations or time takings will be needed for the investigation.

Once we know how many observations will be made, we took the time it takes each of the 3 processes with the 2 pieces (product $\mathrm{A}$ and product $\mathrm{B}$ ) and these were the results obtained:

Milling: part A takes 6.71 minutes and part B takes 8.71 minutes

$>$ Production time is 480 minutes.

> Turning: part A takes 8.71 minutes and part B takes 10.71 minutes. Its production time is 480 minutes.

$>$ Finishing finish: part A takes 11.71 minutes and part B takes 13.71 minutes.

$>$ Its production time is 480 minutes.

$>$ Part A is known to earn $\$ 100$ and part B earns $\$$ 125.

For the phase of modeling, and taking the variables that lead to the process, the mathematical model was then formulated. The mathematical model was as follows:

$$
\begin{gathered}
\operatorname{Max} z: 100 x_{1}+125 x_{2} \\
6.71 x_{1}+8.71 x_{2} \leq 480 \\
8.71 x_{1}+10.71 x_{2} \leq 480 \\
11.71 x_{1}+13.71 x_{2} \leq 480 \\
x_{1}, x_{2} \geq 0
\end{gathered}
$$

Where part A will be the variable $\mathrm{x} 1$ and part $\mathrm{B}$ will be $\mathrm{x} 2$. The mathematical model remained with two variables and three restrictions, due to the processes by which the two products pass.

For the resolution phase of the model, the PHP SIMPLEX ${ }^{\circledR}$ tool was used, because it is a free and easy-to-use software for solving operations research problems. Figure 2 shows the main screen and the entry of the two variables and three restrictions.

\section{PHPSimplex}

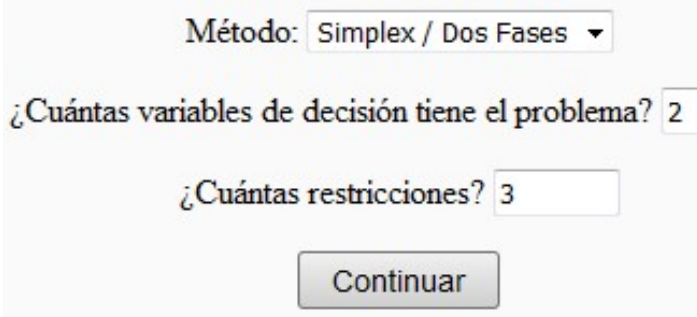

Figure 2. SIMPLEX® PHP main screen

\begin{tabular}{|c|c|c|c|c|c|c|}
\hline 6.71 & $\mathrm{X}_{1}+$ & 8.71 & $\mathrm{X}_{2}$ & $\leq$ & 4 & $\$ 80$ \\
\hline 8.71 & $\mathrm{X}_{1}+$ & 10.71 & $\mathrm{X}_{2}$ & $\leq$ & & 80 \\
\hline 11.71 & $\mathrm{X}_{1}+$ & 13.71 & $\mathrm{X}_{2}$ & $\leq$ & & 180 \\
\hline \multicolumn{7}{|c|}{$\mathrm{X}_{1}, \mathrm{X}_{2} \geq 0$} \\
\hline & & & & & & \\
\hline
\end{tabular}

Then Figure 3 shows the entry of the variables into the PHP SIMPLEX ${ }^{\circledR}$ program.

¿Cuál es el objetivo de la función? Maximizar -

Función: $100 \quad \mathrm{X}_{1}+\mathrm{X}_{2}$

Restricciones:

Figure 3. Example of input variables in PHP SIMPLEX®

The program helps to see how the problem is solved either directly or only the last result. For space saving, the last table of the final result is shown in figure 4.

$$
\begin{aligned}
& \text { La solución óptima es } Z=4376.3676148796 \\
& X_{1}=0 \\
& X_{2}=35.010940919037
\end{aligned}
$$

Figure 4. Final solution in PHP SIMPLEX®

The results of the problem are: Production of piece A equal to 0 , production for piece B 35.01 products and maximum gain is $\$ 4376.36$. 
Special Issue of $2^{\text {nd }}$ International Congress of Engineering

The results obtained by the PHP SIMPLEX ${ }^{\circledR}$ problems. Figure 5 shows the entry of the variables program, compared to the WIN QSB ${ }^{\circledR}$ software, is into the WIN QSB ${ }^{\circ}$ program.

also a program that helps solving operations research

\begin{tabular}{|l|r|r|c|r|}
\hline Variable --> & X1 & \multicolumn{1}{|c|}{ X2 } & Direction & R. H. S. \\
\hline Maximize & 100 & 125 & & \\
\hline C1 & 6.71 & 8.71 & $<=$ & 480 \\
\hline C2 & 8.71 & 10.71 & $<=$ & 480 \\
\hline C3 & 11.71 & 13.71 & $<=$ & 480 \\
\hline LowerBound & 0 & 0 & & \\
\hline UpperBound & $\mathrm{M}$ & $\mathrm{M}$ & & \\
\hline VariableType & Continuous & Continuous & & \\
\hline
\end{tabular}

Figure 5. Example of problem entry in WIN QSB ${ }^{\circledR}$

Once the data is entered, the problem solving step is taken, Figure 6 shows the results of the WIN QSB ${ }^{\circledR}$ program.

\begin{tabular}{|c|c|c|c|c|c|c|c|c|}
\hline & 19:33:31 & & Sunday & January & 24 & 2016 & & \\
\hline & $\begin{array}{l}\text { Decision } \\
\text { Variable }\end{array}$ & $\begin{array}{l}\text { Solution } \\
\text { Value }\end{array}$ & $\begin{array}{l}\text { Unit Cost or } \\
\text { Profit c(i) }\end{array}$ & $\begin{array}{c}\text { Total } \\
\text { Contribution }\end{array}$ & $\begin{array}{l}\text { Reduced } \\
\text { Cost }\end{array}$ & $\begin{array}{l}\text { Basis } \\
\text { Status }\end{array}$ & $\begin{array}{l}\text { Allowable } \\
\text { Min. c[i] }\end{array}$ & $\begin{array}{l}\text { Allowable } \\
\text { Max. c[i] }\end{array}$ \\
\hline 1 & $\times 1$ & $\mathbf{0}$ & 100.0000 & 0 & -6.7651 & at bound & $-\boldsymbol{M}$ & 106.7651 \\
\hline \multirow[t]{4}{*}{2} & $\times 2$ & 35.0109 & 125.0000 & $4,376.3680$ & 0 & basic & 117.0794 & M \\
\hline & Objective & Function & [Max.] = & $4,376.3680$ & & & & \\
\hline & & & & & & & & \\
\hline & Constraint & $\begin{array}{l}\text { Left Hand } \\
\text { Side }\end{array}$ & Direction & $\begin{array}{l}\text { Right Hand } \\
\text { Side }\end{array}$ & $\begin{array}{c}\text { Slack } \\
\text { or Surplus }\end{array}$ & $\begin{array}{l}\text { Shadow } \\
\text { Price }\end{array}$ & $\begin{array}{l}\text { Allowable } \\
\text { Min. RHS }\end{array}$ & $\begin{array}{l}\text { Allowable } \\
\text { Max. RHS }\end{array}$ \\
\hline 1 & C1 & 304.9453 & $<=$ & 480.0000 & 175.0547 & $\mathbf{0}$ & 304.9453 & M \\
\hline 2 & $\mathrm{C} 2$ & 374.9672 & $<=$ & 480.0000 & 105.0328 & $\mathbf{0}$ & 374.9672 & H \\
\hline 3 & $\mathrm{C3}$ & 480.0000 & $<=$ & 480.0000 & 0 & 9.1174 & $\mathbf{0}$ & 614.4538 \\
\hline
\end{tabular}

Figure 6. Example of final resolution in WIN QSB®

The results of the problem are: Production of piece A equal to 0 , production for piece B 35.01 products and maximum gain is $\$ 4376.36$. As you can see the results do not vary, the two softwares are reliable for the use of operations research problems.

For the reality check stage, the results were compared with the original process and it was observed that there was no difference in the behavior of the variables. Finally, the mathematical model was implemented with the original process, and until now the process behaves as expected.

\section{Analysis of results}

The two programs used to solve the problem gave the following results.

$>$ Production of part A equal to 0

$>$ Production for part B 35.01 products

$>$ Maximum profit is $\$ 4376.36$.

The two results were similar, so you can be sure that the result is reliable and the two softwares are recommended for solving these types of problems. 


\section{Conclusión}

In the field of Industrial Engineering, you have many tools to analyze and solve and evaluate a problem. The main purpose of an industrial engineer is to be able to apply the tools to understand his procedure, unfortunately many times, mathematics are taught with a theoretical approach, but the practical approach is neglected.

This project emerged from a classroom and was brought to reality in an industrial process. The simplex method tool was analyzed and applied using ICTs in specialized software, which aided the understanding and resolution of the research.

The applied Simplex method of pertinent form, allows to analyze, to solve and to evaluate a problem integrated by different variables. Improvement in the production planning process was achieved by applying the simplex method.

\section{References}

1) Acevedo Borrego, A. O. y Linares Barrantes, M. C. (2012). El enfoque y rol del ingeniero industrial para la gestión y decisión en el mundo de las organizaciones. Industrial Data, vol. 15, núm. 1, pp. 9-24. Universidad Nacional Mayor de San Marcos. Lima, Perú.

2) Alvarado Boirivant, J. (2009). La programación lineal aplicación de la pequeñas y medianas empresas. Reflexiones, vol. 88, núm. 1, pp. 89105. Universidad de Costa Rica. San José, Costa Rica.

3) Anderson, D., Sweeney, D. y Williams, T. (2004). Métodos cuantitativos para los negocios. $822 \mathrm{p}$. México: Editorial Thomson.

4) Ariza Osorio, Y. (S/A). El método simplex. Simplex primal. Asesoramiento empresarial \& gestión, capacitación y entrenamiento.

5) Bazaraa Monkhtar S., Javis, J. J. (1996). Programación lineal y flujo de redes. Quinta edición. Limusa.

6) Bolaños Rodríguez, E. (2012). Muestra y Muestreo. Asignatura: Estadística para el Desarrollo Tecnológico. Área Académica: Gestión Tecnológica. Escuela Superior e Tizayuca. Universidad Autónoma de Hidalgo.
7) Corominas,

A.

(2010).

Planificación

Agregada Integrada de la Empresa: una propuesta para la clasificación de problemas. XIV Congreso Ingeniería de Organización.

8) Durán, G. (2006). Investigación de operaciones, modelos matemáticos y optimización. Seminario JUNAEB-DII. Centro de Gestión de Operaciones. Departamento de Ingeniería Industrial. Universidad de Chile.

9) Faulin, J. (S/A). Aplicaciones de la Programación Lineal. Universitat Oberta de Catalunya (UOC).

10) Galicia Pérez, S. N. (2013). Modelo matemático determinístico simplex para optimizar los recursos en una distribuidora de materia prima para calzado en la ciudad de Guatemala. Escuela de Administración de Empresas. Facultad de Ciencias Económicas. Universidad de San Carlos de Guatemala. Guatemala.

11) Geovanah. (2017). Las bondades que brinda el método CPS simplex - una ayuda idónea para solucionar cualquier problema. Blog Geovanah.

12) Guédez Fernández, C. (2011). Programación Lineal e Ingeniería Industrial: una Aproximación al Estado del Arte Ingeniería Industrial. Actualidad y Nuevas Tendencias, vol. II, núm. 6, pp. 61-78. Universidad de Carabobo. Carabobo, Venezuela.

13) Henríquez Aguilar, M. E. y Hernández Ramírez, W. E. (2010). Diseño de una guía de aplicación del software Winqsb, para el desarrollo de herramientas cuantitativas de la ingeniería industrial. Departamento de Ingeniería y Arquitectura. Departamento de Ingeniería y Arquitectura. Universidad de el Salvador. Santa Ana. El Salvador. Centro América

14) HILLIER, F. S., LIEBERMAN, G. J., Introducción a la investigación de operaciones, tercera edición, McGraw-Hill, México, 1991.

15) HILLIER, F. S., LIEBERMAN, G. J., Investigación de operaciones, septima edición, McGraw-Hill, México, 2001.

16) Illés, T. \& Terlaky, T. (2002). Pivot versus interior point methods: Pros and cons. European J. Operational Res.

17) IOSA Investigación de Operaciones S.A. (2016). Optimización de Sistemas. Principales trabajos. IOSA Investigación de Operaciones S.A. 
18) Instituto Internacional de Investigación de Tecnología Educativa, S.C. (2009). Método simplex. Unidad 3. Matemáticas para negocios. Instituto Internacional de Investigación de Tecnología Educativa, S.C.

19) Ivanoff R. D. 2005. Programación Lineal: Desarrollo de un sistema informático para la generación de modelos. Facultad de Ingeniería y Tecnología Informática. Carrera de Licenciatura en Sistemas de Información. Universidad de Belgrano. Buenos Aires.

20) Izar Landeta, J. M. (1996). Fundamentos de Investigación de operaciones para administración. Universidad Autónoma de San Luis Potosí. Unidad Zona Media. San Luis Potosí. Mèxico.

21) Jiménez Lozano, G. (2009). Optimización. Primera Edición. Universidad Nacional de Colombia sede Manizales.

22) Kowalski, V., Enríquez, H., Santelices, I. y Mercedes, E. (2015). Enseñanza de algoritmos en Investigación Operativa: un enfoque desde la formación por competencias. Ingeniería Industrial. Actualidad y Nuevas Tendencias, vol. IV, núm. 15, pp. 67-80. Universidad de Carabobo. Carabobo, Venezuela.

23) Lugay Rosas, H. (2014). Software Winqsb aplicaciones prácticas en ingeniería industrial. Facultad de Ingeniería. Universidad Nacional Autónoma de México

24) Marchena, W., Ornelas, C. y González Longatt, F. (2007). Optimización y la Programación Lineal: Una Introducción. Reporte de Investigación. Línea de Investigación: Fuentes Alternas de Energía y Generación Distribuida.

25) Morales Marroquín, M. L. (2012). Optimización de la producción en máquinas en paralelo de inyección de plástico. División de Estudios de Posgrado. Facultad de Ingeniería Mecánica y Eléctrica. Universidad Autónoma de León. San Nicolás de los Garza, Nuevo León. México.

26) PHPSimplex. (2017). PHPSimplex. PHPSimplex.

27) Prawda, J. (2000). Métodos y modelos de investigación de operaciones. Vol. 1. Pag. 22. Editorial Limusa.
28) Rodríguez L., D., Díaz M., Amanda C., Ahumada, D. A. y Guerrero, J. A. (2013). Desarrollo y optimización de una metodología multiresiduo por método simplex para el análisis de plaguicidas en miel de abejas. Revista Colombiana de Química, vol. 42, núm. 1. Universidad Nacional de Colombia. Bogotá, Colombia

29) Rodríguez Talavera, J. C. (2012). Método Simplex. Aplicación e Importancia.

30) Romero, O. Muñoz, D. y Romero, S. (2006). Introducción a la ingeniería, un enfoque industrial. México: International. Thomson Editores.

31) Schwarz, M. (2014). Líneas de Investigación en Ingeniería Industrial. Blog Max Schwarz.

32) Taha Hamdy, A. (2004). Investigación de operaciones. $7^{\mathrm{a}}$ edición. Pearson Educación México.

33) Universidad de la República Oriental del Uruguay. (2016). Que es la investigación de investigaciones. Introducción. Introducción a la Investigación de Operaciones. Notas del curso. Materiales de Estudio. Facultad de Ingeniería. Universidad de la República Oriental del Uruguay.

34) Valencia Sandoval, K. (2015). Introducción al método simplex: forma tabular paso a paso. Centro Universitario Valle de Chalco. Universidad Autónoma del Estado de Mèxico. 